\title{
Seasonal variation of limnological features and trophic state index of two oligotrophic reservoirs of southeast Brazil
}

\author{
S. A. Oliveira ${ }^{a}$ and C. E. M. Bicudo ${ }^{a *}$

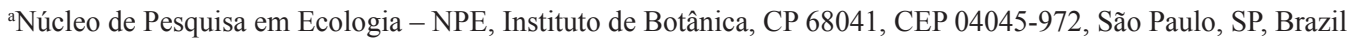 \\ *e-mail: cbicudo@terra.com.br
}

Received: September 8, 2015 - Accepted: February 24, 2016 - Distributed: May 31, 2017

(With 5 figures)

\begin{abstract}
Limnological features of two reservoirs were studied in dry (August 2013) and rainy (January 2014) periods to evaluate the water quality that supply the city of Guarulhos, southeast Brazil. Water samples were collected in three depths and the following characteristics were measured: alkalinity, dissolved $\mathrm{O}_{2}$, free and total $\mathrm{CO}_{2}, \mathrm{HCO}_{3}$, soluble reactive silica, dissolved and total nitrogen and phosphorus, and chlorophyll- $a$. Water transparency was also measured and temperature, $\mathrm{pH}$ and electric conductivity profiles were obtained. Great seasonal and low spatial variability of the water characteristics occurred in the reservoirs. High values of water transparency, free $\mathrm{CO}_{2}$ availability, and low of $\mathrm{pH}$, soluble reactive silica and total and dissolved nutrients values were recorded at the dry period, and different conditions were found at the rainy season. The two reservoirs were characterized by low nutrients, chlorophyll- $a$ and turbidity, and high transparency, these features being typical of oligotrophic systems. The two reservoirs still remain under low anthropogenic impact conditions, and are presently considered reference systems for the SPMR, São Paulo Metropolitan Region. The need for actions that will reduce the input of nutrients from the neighboring cities and the main tributaries of the hydrographic basin is emphasized to maintain the ecological quality of the reservoirs and their reference conditions among the SPRM reservoirs.
\end{abstract}

Keywords: oligotrophy, reference system, reservoir, seasonality.

\section{Variação sazonal das características limnológicas e Índice de Estado Trófico de dois reservatórios oligotróficos do sudeste do Brasil}

\begin{abstract}
Resumo
Características limnológicas de dois reservatórios foram estudadas durante os períodos seco (Agosto 2013) e de chuvas (Janeiro 2014) para avaliar a qualidade da água que abastece a cidade de Guarulhos, Brasil sudeste. Amostras de água foram coletadas em três profundidades e as características estudadas foram: alcalinidade, $\mathrm{O}_{2}$ dissolvido, $\mathrm{CO}_{2}$ livre e total, $\mathrm{HCO}_{3}$, sílica reativa solúvel e nitrogênio e fósforo dissolvido e total e clorofila- $a$. Transparência da água foi medida e obtidos os perfis de temperatura, $\mathrm{pH}$ e condutividade elétrica. Grande variabilidade sazonal e espacial das características da água ocorreu nos reservatórios. Altos valores de transparência da água, disponibilidade de $\mathrm{CO}_{2}$ livre e menores de $\mathrm{pH}$, sílica reativa solúvel e nutrientes totais e dissolvidos foram documentados durante o período seco; e condições diferentes durante o período de chuvas. Os dois reservatórios foram caracterizados por baixos teores de nutrientes, clorofila- $a$ e turbidez e alta transparência, características estas típicas de sistemas oligotróficos. Os dois reservatórios ainda permanecem sob condição de baixo impacto antropogênico e são atualmente considerados sistemas de referência para a RMSP, Região Metropolitana de São Paulo. A necessidade de ações para diminuir e até frear a entrada de nutrientes provenientes das cidades vizinhas e dos principais afluentes da bacia hidrográfica é enfatizada para manter a qualidade ecológica dos reservatórios e suas condições de referência entre os reservatórios da RMSP.
\end{abstract}

Palavras-chave: oligotrofia, sistema de referência, reservatório, sazonalidade.

\section{Introduction}

Maintenance of water resources quality of our Planet is a paramount preoccupation both for the importance of their conservation and their diversified uses. Certain areas in Brazil already have their public supply water reserve partially threatened, especially those of the great urban centers. Among the many reasons that would explain this situation are the inadequate soil use and occupation, the water resources unsustainable management and the great population growth (Tundisi, 2003).

One of the best documented environmental problems that severely affect the aquatic ecosystems at a global scale is the eutrophication (Battarbee et al., 2005). Despite 
the great number of studies emphasizing its sources, the solution for this problem is yet far from being reached (Sayer and Roberts, 2001); consequently, knowledge of the natural conditions of an aquatic system existing prior to any disturbance is fundamental and absolutely crucial for the implementation of recovery strategies and management of potential impacts (Vilaclara et al., 1997).

Regarding the urban reservoirs in particular, most modifications of their water limnological characteristics derive from the hydrographical basin, that is able to vary rapid and intensively due to the nature and composition of its tributaries (Räsänen, 1986). The difficulty in handling reservoirs water quality comes from the dynamic nature of these systems, since they are important convergence points of the different activities being developed in its hydrographic basin (Tundisi et al., 2008). The multiple human activities and their impact surely will reflect on the water ecological quality of such reservoirs (Rebouças, 1999).

Many SPMR, São Paulo Metropolitan Region reservoirs are being pushed by different types of impacts, inferring that the nationwide socio-environmental situation is directly related to the urban growth, the unplanned soil occupation and the threatening urbanization of the hydrographic basins (Tundisi and Matsumura-Tundisi, 2008). The surrounding area of urban reservoirs and their tributaries are increasingly submitted to the punctual factors resulting from the chaotic urban occupation and the insufficiently managed waste and sanitary sewage production that directly affect the aquatic environment equilibrium (Tomanik et al., 2009) and, therefore, the quality of the population water supply. Tanque Grande and Cabuçu reservoirs are used for public supply and provide water for about 1.3 million people, and are included under the above situation.

For Tanque Grande and Cabuçu reservoirs there are only four papers published: Moutinho et al. (2007), Graça et al. (2007), Lacava et al. (2009) and Piasentin et al. (2009). Considering the importance of knowing the quality of the water of these reservoirs for their preservation, present research aimed at contributing to the seasonal evaluation of the limnological aspects and the ecological quality of Tanque Grande and Cabuçu reservoirs through the evaluation of their physical and chemical characteristics.

\section{Material and Methods}

\subsection{Study area}

The two reservoirs are located in the Municipality of Guarulhos, São Paulo State, and southeastern Brazil (Figure 1). Guarulhos is the second largest municipality of the SPMR in terms of population, with c. 1.3 million people. It covers the area of $319 \mathrm{~km}^{2}$, the main city being located northeast of that of São Paulo (2327'49”'S, 46³2'01'W).

Tanque Grande reservoir was built in 1958 at the north region of the municipality $\left(23^{\circ} 22^{\prime} 27^{\prime}\right.$ 'S, $\left.46^{\circ} 27^{\prime} 36^{\prime \prime} \mathrm{W}\right)$. It has the area of $0.54 \mathrm{~km}^{2}$, storage capacity of $77,401 \mathrm{~m}^{3}$, discharge of $315,000 \mathrm{~m}^{3}$ month $^{-1}$ and retention time of 7.35 days (Silva et al., 2011; CETESB, 2014). Its hydrographic basin includes seven streams that will flow into the reservoir responsible for $10 \%$ of the municipality water supply.

Cabuçu reservoir is located in the Cantareira State Park (CSP), at the southern part of the municipality $\left(22^{\circ} 24^{\prime} 06^{\prime \prime S}\right.$, $\left.46^{\circ} 31^{\prime} 56^{\prime \prime} \mathrm{W}\right)$. The reservoir was built in 1904 to water supply the city of São Paulo, being deactivated when the Cantareira system started operating in 2002 (Lacava et al., 2009). The reservoir has a discharge of $300 \mathrm{~L} \mathrm{~s}^{-1}$, the volume of $1,776 \times 10^{6} \mathrm{~L}$ distributed in $1.5 \mathrm{~km}$, total area of over 20 ha and the retention time of 68.51 days (Lacava et al., 2009).

\subsection{Sampling}

Three sampling sites were selected in each reservoir considering the influence of the main tributaries, the water quality heterogeneity and the system depth (Figure 1).

Water samples were collected during the dry (August 2013) and rainy (January 2014) periods, using a van Dorn bottle along a vertical profile (euphotic zone, mean depth and c. $1 \mathrm{~m}$ above the sediments) and placed in polyethylene vials for transportation to the laboratory. Temperature, $\mathrm{pH}$ and electric conductivity profiles were obtained 'in situ' at each $50 \mathrm{~cm}$ of the water column using a Horiba U50 multi-parameter probe.

The following water characteristics were measured: transparency (Secchi disk), alkalinity (Golterman and Clymo, 1969), dissolved oxygen (Golterman et al., 1978), free $\mathrm{CO}_{2}$, total $\mathrm{CO}_{2}$ and $\mathrm{HCO}_{3}$ (Mackereth et al., 1978), ammonium (Solorzano, 1969), nitrate and nitrite (Mackereth et al., 1978), soluble reactive phosphorus, total dissolved phosphorus and soluble reactive silica (Strickland and Parsons, 1965), and total nitrogen and total phosphorus (Valderrama, 1981). Chlorophyll- $a$ (corrected by the phaeophytin) was extracted using ethanol $90 \%$ as the organic solvent (Sartory and Grobbelaar, 1984).

\subsection{Data analysis}

Data were evaluated using Principal Components Analysis (PCA) to ordain the sampling units and the environmental information according to the climatic periods, and were previously transformed by ranging $\left[\left(x-x_{\min }\right) /\left(x_{\max }-x_{\min }\right)\right]$. Randomization test (999 permutations) was employed to understand the PCA dimension $(p<0.05)$. Statistical program used was PC-ORD 6.0 (McCune and Mefford, 2011).

The Trophic State Index (TSI) was calculated according to Lamparelli (2004). Considering the surface total phosphorus and chlorophyll- $a$, TSI can classify the aquatic environment into six trophy categories: TSI $\leq 47$ (ultraoligotrophic), 48-52 (oligotrophic), 53-59 (mesotrophic), 60-63 (eutrophic), 64-67 (supereutrophic) and $>67$ (hypereutrophic).

\section{Results}

Air temperature and the average monthly precipitation were greater in January (respectively $26.8^{\circ} \mathrm{C}, 137.9 \mathrm{~mm}$ ) than in August $\left(18.7^{\circ} \mathrm{C}, 8.2 \mathrm{~mm}\right)$. The water surface temperature followed the same pattern between the two climatic periods, with their average values higher in January 


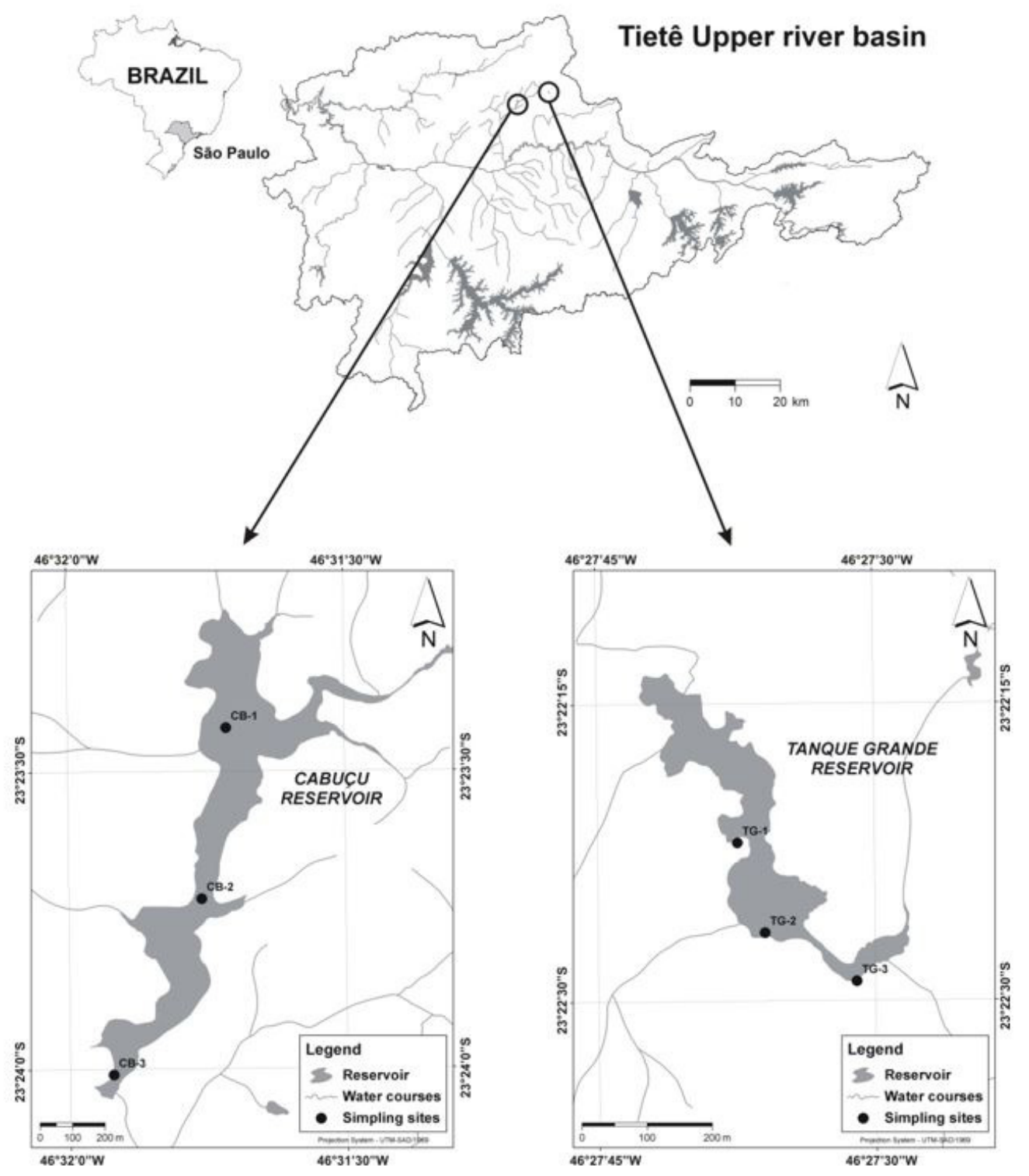

Figure 1. Geographic location of Cabuçu (at left) and Tanque Grande (at right) reservoirs and respective sampling sites.

(Tanque Grande $26^{\circ} \mathrm{C}$, Cabuçu $22.6^{\circ} \mathrm{C}$ ) and lower in August (Tanque Grande $18.2^{\circ} \mathrm{C}$, Cabuçu $16^{\circ} \mathrm{C}$ ).

Secchi disk depth was higher during August at all sampling sites of both reservoirs, showing little variation among sampling sites. During August, the lowest values were measured at the in-between sites and during January, the highest values were measured near the dam (Tables 1,2).

At the Tanque Grande reservoir, $\mathrm{pH}$ (Tables 1,2) was slightly acidic during the two climatic periods, getting close to neutral mainly during January. At the Cabuçu, however, $\mathrm{pH}$ varied from slightly acidic to alkaline, its lowest values recorded in August. Highest electric conductivity was observed at the Tanque Grande reservoir, and the values varied between 49 and $64 \mu \mathrm{S} \mathrm{cm}^{-1}$ in August and between
62 and $67 \mu \mathrm{S} \mathrm{cm}^{-1}$ in January. At the Cabuçu reservoir, however, its variation was slightly lesser in August and the values were homogeneous along the water column during the entire period, whereas in January their values increased towards the bottom of reservoir (Tables 1, 2).

Tanque Grande free $\mathrm{CO}_{2}$ concentrations were higher in August than in January. At the Cabuçu the highest values were measured in January. Considering the vertical distribution, highest values were registered at the surface and sometimes at the intermediate layers, but some other times mostly at the bottom of reservoir (Tables 1, 2). Dissolved oxygen showed a homogeneous distribution at the Tanque Grande water column, but slightly greater in August (Table 1). Dissolved $\mathrm{O}_{2}$ in Cabuçu reservoir 


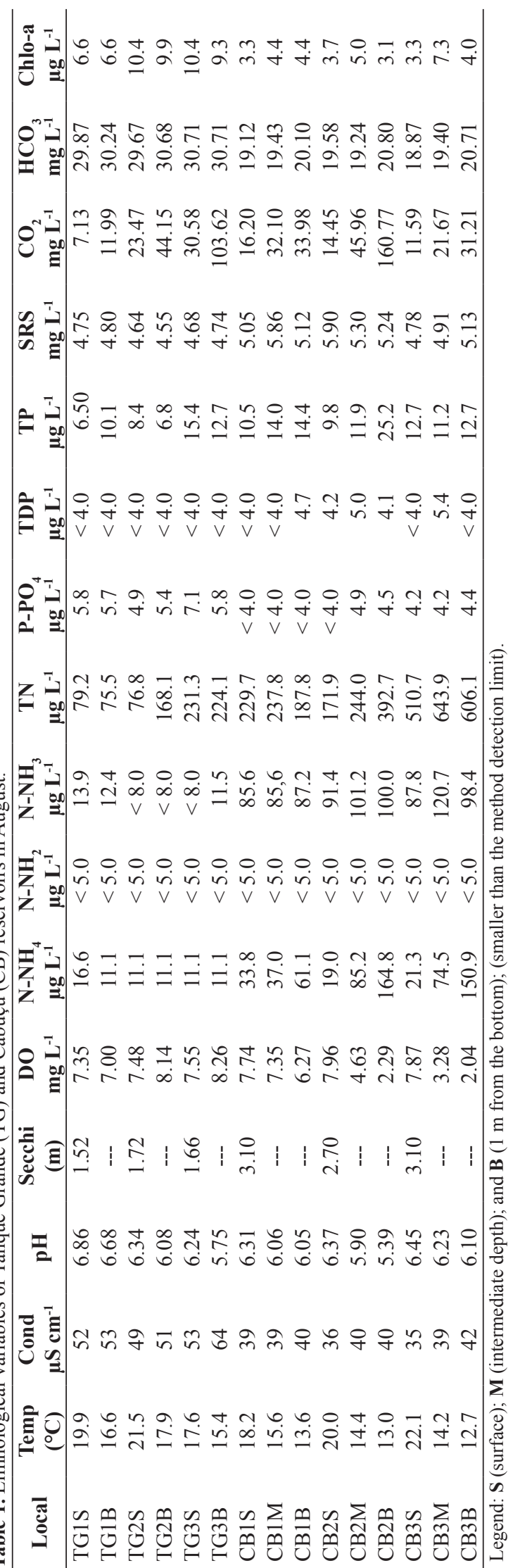

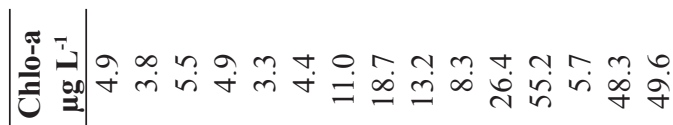

겅ำ 栭

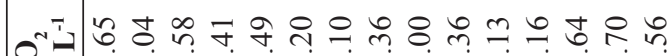
U

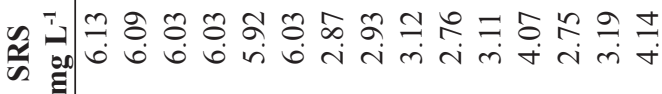

* İ

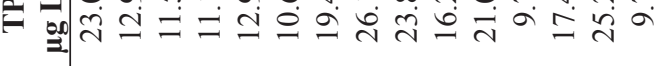

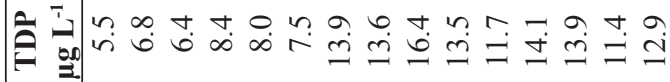
苟 Z تَ山

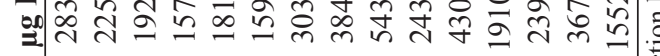

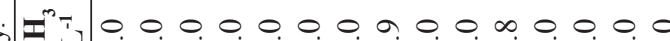

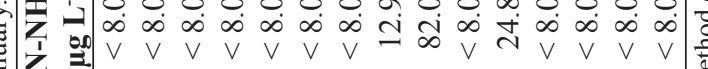

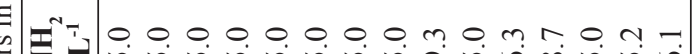
$\stackrel{0}{0}$ อิ

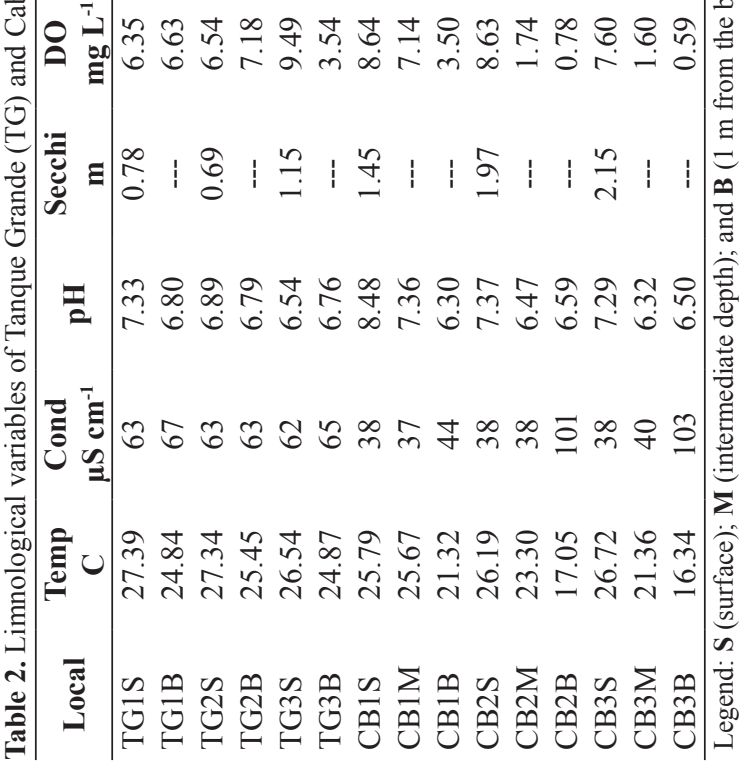


showed a tendency towards its reduction to the bottom of reservoir. In January, however, the tendency was more stressed at all sampling sites, the bottom concentrations almost reaching anoxia (Table 2).

The $\mathrm{N}$ series $\left(\mathrm{NH}_{4}, \mathrm{NO}_{3}\right.$ and $\left.\mathrm{TN}\right)$ exhibited in Tanque Grande reservoir low and similar values in the two climatic periods sampled (Tables 1, 2, Figure 2). At the Cabuçu reservoir, the highest $\mathrm{NH}_{4}$ values were recorded in January, whereas those of $\mathrm{NO}_{3}$ were in August. Highest values of TN were found in January, and an increasing gradient was observed towards the bottom of reservoir (Tables 1, 2, Figure 2a, b and c).

Phosphorus total and dissolved forms showed low values, in some cases below the method detection limit as was the case of dissolved TP of Tanque Grande reservoir in August. At the Cabuçu reservoir, P dissolved fractions were low in August. Highest TP values were detected in January, and the greatest ones at the reservoir surface (Table 2, Figure 2f). Regarding the spatial scale, TP highest values were obtained at the sampling sites located near to the tributaries entrance.

Tanque Grande surface chlorophyll- $a$ concentrations were higher in August, whereas at the Cabuçu reservoir the opposite occurred, i.e. the highest values being obtained in January (Tables 1, 2, Figure 3).

Principal Components Analysis considering 12 limnological variables resumed $64.8 \%$ of data total variability (Table 3, Figure 4). August sampling units
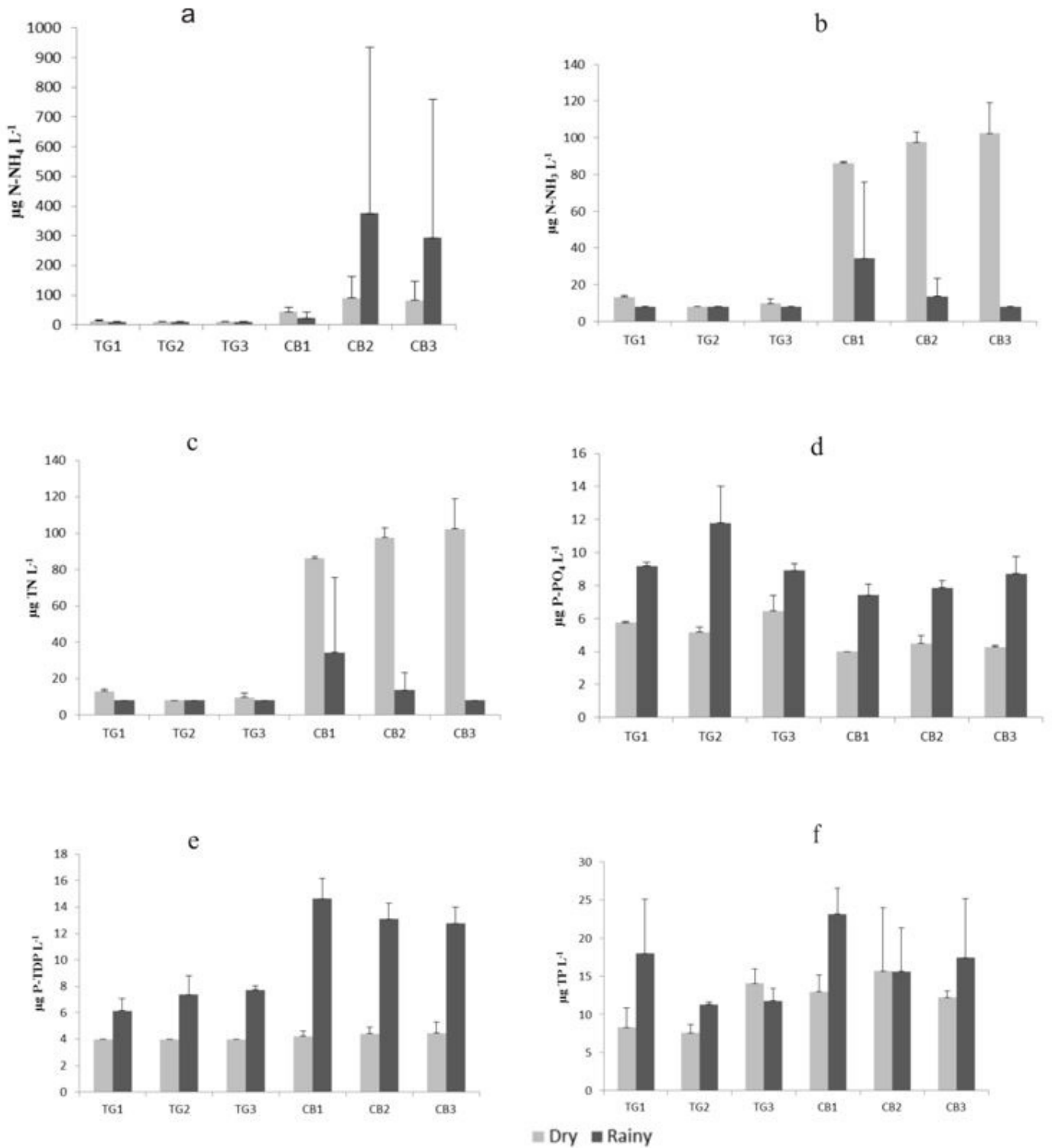

Figure 2. Ammonium (a), Nitrate (b), Total nitrogen (c), Orthophosphate (d), Total dissolved phosphorus (e) and Total phosphorus (f) concentrations (average $\pm \mathrm{SD}$ ) of Tanque Grande and Cabuçu reservoirs during the two climatic periods. 


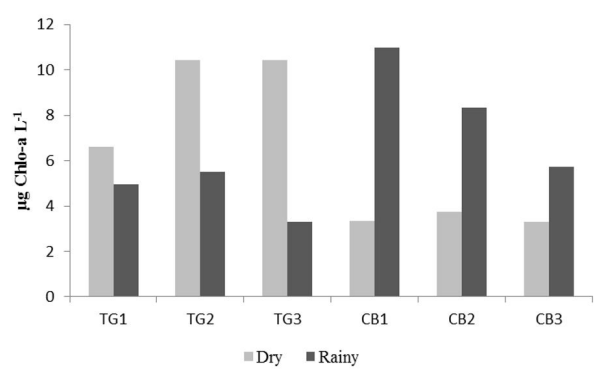

Figure 3. Chlorophyll- $a$ concentration $\left(\mu \mathrm{g} \mathrm{L}^{-1}\right)$ at the surface of Tanque Grande and Cabuçu reservoirs during the two climatic periods studied.

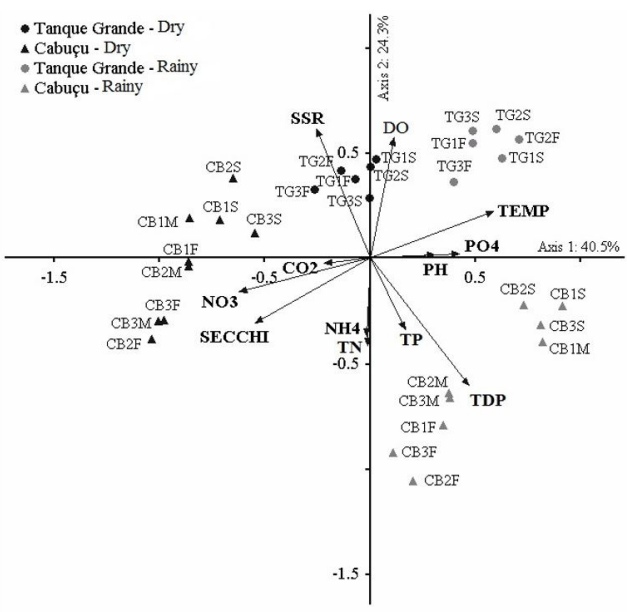

Figure 4. Principal Components Analyses (PCA) based on 12 limnological variables of the sampling sites of Tanque Grande (TG) and Cabuçu (CB) reservoirs during August and January of present study. Legend: S (surface); M (intermediate depth); and $\mathrm{F}$ ( $1 \mathrm{~m}$ from the bottom).

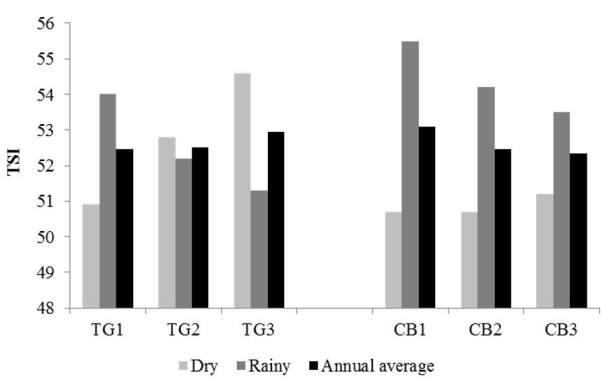

Figure 5. Trophic State Index of Tanque Grande and Cabuçu reservoirs during August and January. gathered at the negative side of axis 1 were mainly associated with the water transparency (Secchi disk) and $\mathrm{NO}_{3}(\mathrm{r}>0.8)$ greatest values as well as the lowest ones of temperature and dissolved TP. At the positive side of this axis were assembled the January sampling units associated to the highest temperature, $\mathrm{PO}_{4}$ and $\mathrm{pH}(\mathrm{r}>0.8)$ values and the smallest ones of water transparency and $\mathrm{NO}_{3}$. At the positive side of axis 2, were the Tanque Grande sampling units and some surface sampling units of the Cabuçu reservoir intermediate region, associated to the DO and SRS highest values $(r>0.7)$. At the negative side of this axis, Cabuçu sampling units were positioned associated to the highest $\mathrm{TN}$ and $\mathrm{NH}_{4}$ values $(\mathrm{r}>0.6)$ and the lowest ones of DO and SRS. Thus, axis 1 ordained the sampling units in regard to seasonality, whereas axis $2 \mathrm{did}$ it in relation to the reservoir's compartments differences.

The Trophic State Index (Figure 5) classified oligotrophic the Tanque Grande reservoir in August, except for the pelagic zone that was considered mesotrophic. In January the opposite occurred, i.e. the reservoir was classified mesotrophic and its sampling site TG3 oligotrophic. The Cabuçu reservoir was classified oligotrophic in August and mesotrophic in January. Considering the TSI annual average, however, both reservoirs were classified oligotrophic, except for its upstream sampling site that was classified mesotrophic (Table 4).

\section{Discussion}

The greatest limnological variation currently observed for the Guarulhos Producing System occurred according to the seasonal scale (dry and rainy periods), an already known characteristic of tropical and subtropical reservoirs (Naselli-Flores, 1999; Ferrareze et al., 2005; Sartori et al., 2009). Differences among reservoirs were also detected.

Temperature values followed the pattern defined for the tropical region, i.e. mild during August and higher in January. Surface water temperature is affected by several factors including depth and the presence of surrounding vegetation (Percebon et al., 2005). It was presently observed that milder temperatures were registered at the Cabuçu reservoir due to its well preserved surroundings, differently than in Tanque Grande when $4^{\circ} \mathrm{C}$ and $2^{\circ} \mathrm{C}$ were recorded in January and August, respectively.

A joint evaluation of abiotic data indicated that both reservoirs were similar in August mainly because of the greatest water transparency and DO values and of $\mathrm{CO}_{2}$, SRS and $\mathrm{NO}_{3}$ availability, and the smallest values of

Table 3. Correlation of the limnological variables with PCA axes 1 and 2 (between parentheses: acronyms).

\begin{tabular}{lrrlrr}
\hline \multicolumn{1}{c}{ Variable } & Axis 1 & Axis 2 & \multicolumn{1}{c}{ Variable } & Axis 1 & Axis 2 \\
\hline Temperature $($ Temp $)$ & $\mathbf{0 . 8 6 8}$ & 0.255 & Total nitrogen $(T N)$ & -0.027 & $-\mathbf{0 . 7 3 1}$ \\
pH & 0.772 & 0.022 & Total phosphorus $(T P)$ & 0.278 & -0.446 \\
Secchi depth & $\mathbf{- 0 . 8 1 5}$ & -0.359 & Silicate $(S S R)$ & -0.373 & $\mathbf{0 . 6 9 6}$ \\
Dissolved oxygen $(D O)$ & 0.184 & $\mathbf{0 . 7 2 4}$ & Orthophosphate $\left(P O_{4}\right)$ & $\mathbf{0 . 8 2 4}$ & 0.030 \\
Ammonium $\left(\mathrm{NH}_{4}\right)$ & -0.042 & $\mathbf{- 0 . 6 2 1}$ & Free $\mathrm{CO}_{2}\left(\mathrm{CO}_{2}\right)$ & -0.535 & -0.052 \\
Nitrate $\left(\mathrm{NO}_{3}\right)$ & $\mathbf{- 0 . 8 3 8}$ & -0.168 & Total dissolved phosphorus $(T D P)$ & 0.675 & -0.682 \\
\hline
\end{tabular}


Table 4. Trophic State Index for chlorophyll- $a$ (TSI Chlo-a) and total phosphorus (TSI TP), average index (TSI average) and yearly classification Meso (mesotrophic), Oligo (oligotrophic). Aug (August), Jan (January).

\begin{tabular}{|c|c|c|c|c|c|c|c|c|c|c|}
\hline \multirow{2}{*}{ Reservoir } & \multirow{2}{*}{ Site } & \multicolumn{2}{|c|}{ TSI Chlo-a } & \multicolumn{2}{|c|}{ TSI TP } & \multicolumn{2}{|c|}{ TSI average } & \multicolumn{3}{|c|}{ Classification } \\
\hline & & Aug & Jan & Aug & Jan & Aug & Jan & Aug & Jan & Annual \\
\hline \multirow{3}{*}{ Tanque Grande } & TG1 & 56.0 & 54.6 & 45.8 & 53.5 & 50.9 & 54.0 & Oligo & Meso & Oligo \\
\hline & TG2 & 58.2 & 55.1 & 47.3 & 49.3 & 52.8 & 52.2 & Oligo & Meso & Oligo \\
\hline & TG3 & 58.2 & 52.6 & 51.0 & 50.0 & 54.6 & 51.3 & Meso & Oligo & Oligo \\
\hline \multirow{3}{*}{ Cabuçu } & CB1 & 52.6 & 58.5 & 48.7 & 52.4 & 50.7 & 55.5 & Oligo & Meso & Meso \\
\hline & $\mathrm{CB} 2$ & 53.2 & 57.1 & 48.3 & 51.3 & 50.7 & 54.2 & Oligo & Meso & Oligo \\
\hline & CB3 & 52.6 & 55.3 & 49.9 & 51.8 & 51.2 & 53.5 & Oligo & Meso & Oligo \\
\hline
\end{tabular}

temperature, $\mathrm{pH}, \mathrm{PO}_{4}$ and dissolved TP. In January, the reverse occurred, i.e. lower values of water transparency and $\mathrm{DO}$, of $\mathrm{CO}_{2}$, SRS and $\mathrm{NO}_{3}$ availability, and greater values of temperature, $\mathrm{pH}, \mathrm{PO}_{4}$ and dissolved TP.

Water transparency was greater in August than in January, and was related to the lower amount of precipitation that led to a lesser input of particulate material during the period, as was registered by Wengrat and Bicudo (2011) for the Billings Complex.

Heterogeneous pattern of dissolved oxygen distribution along the water column was found in August, with a concentration reduction with depth. $\mathrm{O}_{2}$ concentration reduction at the bottom of reservoir shall be related to the organic matter decomposition at the bottom of reservoir, which led to a high $\mathrm{CO}_{2}$ production and, consequently, to a high $\mathrm{O}_{2}$ consumption (Hill et al., 1993).

$\mathrm{pH}$ variation range in the two reservoirs studied is characteristic of unpolluted continental waters (Kalff, 2002). Both reservoirs exhibited similar $\mathrm{pH}$ values along the water column and also among the sampling sites, however slightly smaller in August. In relation to the several factors affecting the $\mathrm{pH}$, interpretation in nature may become somewhat complex (Esteves, 2011). According to Nascimento (2012), smaller $\mathrm{pH}$ favors an increase of $\mathrm{CO}_{2}$ concentrations depending on the equilibrium between $\mathrm{pH}$ and the carbon inorganic forms, similar to what was observed in the present study. Furthermore, higher $\mathrm{CO}_{2}$ values may be associated with the increase of respiration and the organic matter decomposition processes (Branco, 1966).

Soluble reactive silica availability seems to be related to the stratification and circulation periods. Circulation allows a greater SRS availability along the water column (Wetzel, 2001). Nevertheless, during the present study the smallest SRS concentrations were measured. A small variation of temperature in relation to the increase in depth leads to a homogeneous SRS distribution along the water column and the reduction of Si concentration at the reservoir surface (Esteves, 2011).

Both reservoirs were characterized by a low nutrient concentration in total and dissolved forms that are emblematic of oligotrophic systems (Arcifa et al., 1981; Bicudo et al., 2002; Lopes et al., 2005; Tundisi et al., 2006). However, integration of the limnological data allowed also differences between the two reservoirs. Thus, Cabuçu showed higher $\mathrm{TP}$ and TN and a higher $\mathrm{HCO}_{3}$ availability when compared to Tanque Grande reservoir. Considering that the latter reservoir is inserted in a preservation area ("Reserva
Florestal do Núcleo Cabuçu”) it is much probable that its enrichment is a natural process.

Longitudinal gradient in reservoirs represented by the zones under influence of the system regimen flux differ from each other in terms of their local physical, chemical and biological characteristics (Thorton et al., 1990). Variation in the nutrient contents along the longitudinal gradient was already observed in several reservoirs, as in Segredo (Thomaz et al., 1997) and Salto Grande (Zanata and Espíndola, 2002). In the present study, similarity among the sampling sites of each reservoir was observed. This fact should be associated to that of the reservoirs having about the same depth along their entire extensions.

Both Tanque Grande and Cabuçu reservoirs were classified oligotrophic, except for the Cabuçu upstream sampling site classified mesotrophic $(\mathrm{TSI}=53.1)$, however, very close to the oligotrophy zone upper limit (TSI $=47-52$ ). Downstream sampling site was classified mesotrophic mainly because of the influence of its greater August chlorophyll- $a$ values. However, such results compared to the eutrophic reservoirs like the Guarapiranga at its intake site $\left(57.74 \mu \mathrm{g} \mathrm{L}^{-1}\right)$ and the Billings main body $\left(65.22 \mu \mathrm{g} \mathrm{L}^{-1}\right)$ (CETESB, 2014) should be considered somewhat low. Present values coincide with those measured for oligotrophic to mesotrophic reservoirs like Jaguari-Jacareí (Nascimento, 2012: $<8.3 \mu \mathrm{g} \mathrm{L}^{-1}$ ), Pedro Beicht (Silva, 2012: $9.5 \mu \mathrm{g} \mathrm{L}^{-1}$ ), Ribeirão Perová $\left(<0.01 \mu \mathrm{g} \mathrm{L}^{-1}\right)$ and Ribeirão dos Cristais $\left(0.76 \mu \mathrm{g} \mathrm{L}^{-1}\right)$ mentioned in CETESB (2014).

\section{Conclusion}

The Guarulhos Producing System showed low dissolved nutrient's concentrations, besides low values of total phosphorus and chlorophyll- $a$, that are characteristic of the reservoir's oligo-mesotrophic classification. Also were coincident due to slightly acidic $\mathrm{pH}$ and good oxygen availability. These characteristics indicate that Tanque Grande and Cabuçu reservoirs are still subjected to small anthropogenic impact and/or some satisfactory level of alteration.

\section{Acknowledgements}

This work was supported by funds provided by FAPESP, Fundação de Amparo à Pesquisa do Estado de São Paulo (Project $n^{\circ}$ 2009/53898-9). SAO and CEMB thank CNPq, 
Conselho Nacional de Desenvolvimento Científico e Tecnológico for the scholarship granted to the first author and to research grant to the second one (CEMB). Authors are also grateful to Prof. William de Queiróz (Universidade de Guarulhos, Geoprocessing Laboratory) for providing the illustration of the study area.

\section{References}

ARCIFA, M.S., CARVALHO, M.A.J., GIANESELLA-GALVÃO, S.M.F., SHIMIZU, G.Y., FROEHLICH, C.G. and CASTRO, R.M.C., 1981. Limnology of ten reservoirs in Southeastern Brazil. Verhandlungen der Internationale Vereinigung der Limnologie, vol. 21, pp. 1048-1053.

BATTARBEE, R.W., ANDERSON, N.J.E. and JEPPENSEN, E., 2005. Combining paleolimnological and limnological approaches in assessing lake ecosystem response to nutrient reduction. Freshwater Biology, vol. 50, no. 10, pp. 1772-1780. http://dx.doi. org/10.1111/j.1365-2427.2005.01427.x.

BICUDO, D.C., FORTI, M.C., CARMO, C.F.C., BOUROTTE, C., BICUDO, C.E.M., MELFI, A. and LUCAS, Y., 2002. A atmosfera, as águas superficiais e os reservatórios no PEFI: caracterização química. In: D.C. BICUDO, M.C. FORTI and C.E.M. BICUDO, eds. Parque Estadual das Fontes do Ipiranga: unidade de conservação ameaçada pela urbanização de São Paulo. São Paulo: Secretaria do Meio Ambiente do Estado de São Paulo, pp. 161-200.

BRANCO, S.M., 1966. Estudos das condições sanitárias da Represa Billings. Arquivos da Faculdade de Higiene e Saúde Pública, vol. 20, no. 1, pp. 57-86. http://dx.doi.org/10.11606/ issn.2358-792X.v20i1p57-86.

COMPANHIA DE TECNOLOGIA DE SANEAMENTO AMBIENTAL - CETESB, 2014. [viewed 10 October 2014]. Relatório de qualidade das águas interiores do Estado de São Paulo, 2013 [online]. Relatório Técnico. Available from: http:// aguasinteriores.cetesb.sp.gov.br/

ESTEVES, F.A., 2011. Fundamentos de limnologia. 2nd ed. Rio de Janeiro: Interciência.

FERRAREZE, M.F.F., NOGUEIRA, M.G. and VIANNA, N.C., 2005. Transporte de nutrientes e sedimentos no rio Paranapanema (SP/PR) e seus principais tributários nas estações seca e chuvosa. In: M.G. NOGUEIRA, R. HENRY and A. JORCIN, eds. Ecologia de reservatórios: impactos potenciais, ações de manejo e sistemas em cascata. São Carlos: Editora RiMa, pp. 435-459.

GOLTERMAN, H.L. and CLYMO, R.S., 1969. Methods for chemical analysis of freshwaters. Oxford: Blackwell Scientific Publications. IBP Handbook, no. 8.

GOLTERMAN, H.L., CLYMO, R.S. and OHMSTAD, M.A., 1978. Methods for physical and chemical analysis of freshwaters. 2nd ed. Oxford: Blackwell Scientific Publications.

GRAÇA, S., GARCIA, M.J. and OLIVEIRA, P.E., 2007. Flora diatomácea moderna do Lago Estância das Águas Claras, Guarulhos (SP): resultados qualitativos. Revista UnG - Geociências, vol. 6, p. 63-79.

HILL, J.W., FEIGL, D.M. and BAUM, S.J., 1993. Chemistry and life: an introduction to general, organic, and biological chemistry. 4th ed. New York: Macmillan.

KALFF, J., 2002. Limnology. New Jersey: Prentice Hall.
LACAVA, M.A., OLIVEIRA, A.M.S. and PEREIRA-FILHO, J.P., 2009. Comportamento hídrico de superfície da bacia do Rio Cabuçu de Cima, Parque Estadual da Cantareira, Guarulhos, SP. Revista Brasileira de Geomorfologia, vol. 10, pp. 23-30.

LAMPARELLI, M.C., 2004. Graus de trofia em corpos d'água do Estado de São Paulo: avaliação dos métodos de monitoramento. São Paulo: Universidade de São Paulo, 235 p. Tese de Doutorado em Ciências na Área de Ecossistemas Terrestres e Aquáticos.

LOPES, M.R.M., BICUDO, C.E.M. and FERRAGUT, M.C., 2005. Short term spatial and temporal variation of phytoplankton in a shallow oligotrophic reservoir, southeast Brazil. Hydrobiologia, vol. 542, no. 1 , pp. $235-247$. http://dx.doi.org/10.1007/s10750004-8332-z.

MACKERETH, F.J.H., HERON, J. and TALLING, J.F., 1978. Water analysis: some revised methods for limnologists. Kendall: Ed. Wilson, Son Ltda. 117 p. Freshwater Biological Association Scientific Publication, no. 39.

MCCUNE, B. and MEFFORD, M.J., 2011. PC-ORD. Multivariate analysis of ecological data. Version 6.0 [software]. Gleneden Beach, Oregon: MjM Software.

MOUTINHO, S.O., GARCIA, M.J. and OLIVEIRA, P.E., 2007. Flora de diatomáceas do Reservatório Cabuçu, Município de Guarulhos (SP): análise qualitativa. Revista UnG. Geociências, vol. 6 , no. 1 , pp. 32-62.

NASCIMENTO, M.N., 2012. Biodiversidade e distribuição das diatomáceas planctônicas e de sedimento superficial em represa profunda oligotrófica (Sistema Cantareira, Represa JaguariJacareí). São Paulo: Instituto de Botânica, 151 p. Dissertação de Mestrado em Biodiversidade Vegetal e Meio Ambiente.

NASELLI-FLORES, L., 1999. Limnological aspects of Sicilian reservoirs: a comparative ecosystemic approach. In: J.G. TUNDISI and M. STRAŠKRABA, eds. Theoretical reservoir ecology and its applications. Leiden: Backhuys Publishers, pp. 283-311.

PERCEBON, C.M., BITTENCOURT, A V.L. and ROSA-FILHO, E.F., 2005. Diagnóstico da temperatura das águas dos principais rios de Blumenau, SC. Boletim Paranaense de Geociências, vol. 56, pp. 7-19.

PIASENTIN, A.M., SEMENSATTO-JUNIOR, D.L., SAAD, A.R., MONTEIRO-JUNIOR, A.J. and RACZKA, M.F., 2009. Índice de Qualidade da Água (IQA) do reservatório Tanque Grande Guarulhos (SP): Análise sazonal e efeitos do uso e ocupação do solo. Geociências, vol. 28, pp. 305-317.

RÄSÄNEN, M., 1986. Recent sedimentation in a freshwater reservoir in SW-Finland: the diatomological and chemical evidence of sediments on the development of the water body. Hydrobiologia, vol. 143, pp. 361-369. http://dx.doi.org/10.1007/BF00026684.

REBOUÇAS, A.C., 1999. Água doce no mundo e no Brasil. In: A.C. REBOUÇAS, B. BRAGA and J.G. TUNDISI, eds. Águas doces do Brasil: capital ecológico, uso e conservação. São Paulo: Escrituras Editora, pp. 1-37.

SARTORI, A.A.C., BARBOSA, A.P., PISANI, R.J., OLIVEIRA, F.O. and ZIMBACK, C.R.L., 2009. Mapeamento de conflitos de solo em áreas de preservação permanente na Bacia Experimental do Rio Pardo, São Paulo, Brasil. In: Anais do XIV Simpósio Brasileiro de Sensoriamento Remoto, 2009, Natal. Natal: INPE, pp. 6197-6202.

SARTORY, D.P. and GROBBELAAR, J.U., 1984. Extraction of chlorophyll a from freshwater phytoplankton for spectrophotometric 
analysis. Hydrobiologia, vol. 114, no. 3, pp. 177-187. http://dx.doi. org/10.1007/BF00031869.

SAYER, C.D. and ROBERTS, N., 2001. Establishing realistic restoration targets for nutrientenriched shallow lakes: linking diatom ecology and paleoecology at the Attenborough Ponds, U.K. Hydrobiologia, vol. 448, no. 1/3, pp. 117-142. http://dx.doi. org/10.1023/A:1017597221052.

SILVA, C., OLIVEIRA, A.M.S., FIGUEIRA, R.C.L., SEMENSATTO, D. and LABUTO, G., 2011. Estudo do assoreamento do Reservatório Tanque Grande, Guarulhos (SP). Geociências, vol. 30, no. 2, pp. 253-267.

SILVA, P.D.A., 2012. Biodiversidade e distribuição das diatomáceas planctônicas e de sedimento superficial nas represas de abastecimento do Sistema Alto Cotia (SP). São Paulo: Instituto de Botânica, 98 p. Dissertação de Mestrado em Biodiversidade Vegetal e Meio Ambiente.

SOLORZANO, L., 1969. Determination of ammonia in natural waters by the phenol hypochlorite method. Limnology and Oceanography, vol. 14, pp. 799-801.

STRICKLAND, J.D. and PARSONS, T.R., 1965. A manual of sea water analysis. Bulletin of the Fisheries Board of Canada, vol. 125 , pp. 1-185.

THOMAZ, S.M., ROBERTO, M.C. and BINI, L.M., 1997. Caracterização limnológica dos ambientes aquáticos e influência dos níveis fluviométricos. In: A.E.A. VAZZOLER, A.A. AGOSTINHO and N.S. HAHN, eds. A planície de inundação do alto rio Paraná: aspectos fisicos, biológicos e sócio-econômicos. Maringá: Editora Universidade de Maringá. pp. 73-102.

THORTON, K.W., KIMMEL, B.L. and PAYNE, F.E., 1990. Perspectives on reservoir limnology. In: K.W. THORTON, B.L. KIMMEL and F.E. PAYNE, eds. Reservoir limnology: ecological perspectives. New York: Wiley-Interscience, pp. 1-13.

TOMANIK, E.A., PAIOLA, L.M., MARTÍNEZ-FERNÁNDEZ, J.B. and FERNANDES, S.L., 2009. Environmental changes and human work in the region of the Upper Paraná River floodplain: processes and interactions. Brazilian Journal of Biology $=$ Revista Brasileira de Biologia, vol. 69, no. 20, (suppl.), pp. 583-589. http:// dx.doi.org/10.1590/S1519-69842009000300013. PMid:19738965.
TUNDISI, J.G. and MATSUMURA-TUNDISI, T., 2008. Limnologia. São Paulo: Oficina de Textos.

TUNDISI, J.G., 2003. Água no século XXI: enfrentando a escassez. São Carlos: Editora RiMa.

TUNDISI, J.G., MATSUMURA-TUNDISI, T. and GALLI, C.S., 2006. Reservatórios da Região Metropolitana de São Paulo: consequências e impactos da eutrofização e perspectivas para o gerenciamento e recuperação. In: J.G. TUNDISI, T. MATSUMURA-TUNDISI and C.S. GALLI, eds. Eutrofização na América do Sul: causas, consequências e tecnologias de gerenciamento e controle. Rio de Janeiro: IIE/IIEGA/ABC/IAP/ Ianas, pp. 161-180.

TUNDISI, J.G., MATSUMURA-TUNDISI, T. and TUNDISI, J.E., 2008. Reservoirs and human well being new challenges for evaluating impacts and benefits in the neotropics. Brazilian Journal of Biology $=$ Revista Brasileira de Biologia, vol. 68, no. 4, (suppl.), pp. 1133-1135. http://dx.doi.org/10.1590/S151969842008000500020. PMid:19197483.

VALDERRAMA, J.C., 1981. The simultaneous analysis of total nitrogen and total phosphorus in natural waters. Marine Chemistry, vol. 10, no. 2 , pp. 109-122. http://dx.doi.org/10.1016/03044203(81)90027-X.

VILACLARA, G., RICO, R. and MIRANDA, J., 1997. Effects of perturbations on diatom assemblages in Tlaxcala paleolake, México. Verhandlungen der Internationale Vereinigung der Limnologie, vol. 26, pp. 846-851.

WENGRAT, S. and BICUDO, D.C., 2011. Spatial evaluation of water quality in an urban reservoir (Billings Complex, southeastern Brazil). Acta Limnologica Brasiliensia, vol. 23, no. 2, pp. 200216. http://dx.doi.org/10.1590/S2179-975X2011000200010.

WETZEL, R.G., 2001. Limnology: lake and river ecosystems. San Diego: Academic Press.

ZANATA, L.H. and ESPÍNDOLA, E.L., 2002. Longitudinal processes in Salto Grande reservoir (Americana, SP, Brazil) and its influence in the formation of compartment system. Brazilian Journal of Biology $=$ Revista Brasileira de Biologia, vol. 62, no. 2, pp. 347-361. http://dx.doi.org/10.1590/S1519-69842002000200019. PMid:12489407. 